\title{
Glocal trends and employer ratings as a critical branding approach in the social economy
}

\author{
Michael P. Heide ${ }^{1, *}$ \\ ${ }^{1}$ Babeş-Bolyai University Cluj-Napoca, Faculty of Economics and Business Administration, \\ Department of Marketing, Romania
}

\begin{abstract}
Research background: The global corona pandemic that broke out at the beginning of 2020 is considered a catalyst for the necessary digitization of organizations - including in the social economy. In addition to social issues, the corona crisis primarily affects the economic framework, in particular securing liquidity to maintain business activity. Furthermore, the shortage of skilled workers is exacerbated by the change to the labor market. At the same time, Generation $Y$ is populating the job market with their changed demands and is presenting employers with central challenges. This primarily includes maintaining the innovation and competitiveness of the socioeconomic organization.

Purpose of the article: The aim of this research contribution is to show organizations how information from web-based employer review portals can be used for decision-making. The focus is on the identification of critical success factors for the organization-specific stakeholder orientation, especially for employer branding.

Methods: The author has analyzed secondary data due to the pandemic in order to identify and systematize HR tendencies. In doing so, available (online) data from Bitkom was used, supplemented by ratings and comments on the web platform for employer ratings kununu.com.

Findings \& Value added: Employer rating portals are developing into an interactive forum and shaping the image of employers - employer branding, which is supported by social media. The design of an attractive employer brand must be understood as a strategic management task in social economy organizations.
\end{abstract}

Keywords: COVID-19 pandemic; Digitalization; Online rating portals; Employer branding; Social economy

JEL Classification: $L 31 ; M 10 ; M 12 ; M 31 ; O 15$

\footnotetext{
* Corresponding author: michael.heide@econ.ubbcluj.ro
} 


\section{Introduction}

Many organizations in the VUCA world are undergoing a fundamental change that is being shaped by digitization and the global corona pandemic. What began as a result of the digital transformation in the context of the megatrends is catalyzed by the SARS-CoV2 virus (Kröger \& Marx, 2020; Ulrich et al., 2021). The associated economic effects require a strategic rethink in the management of (socio-economic) organizations (Heide et al., 2021). Communication influences the acceptance process of management decisions at the operational level (Einwiller et al., 2021). Figure 1 below shows the development of the corporate landscape. Kröger \& Marx (2020) also speak of the so-called Taylor tub.

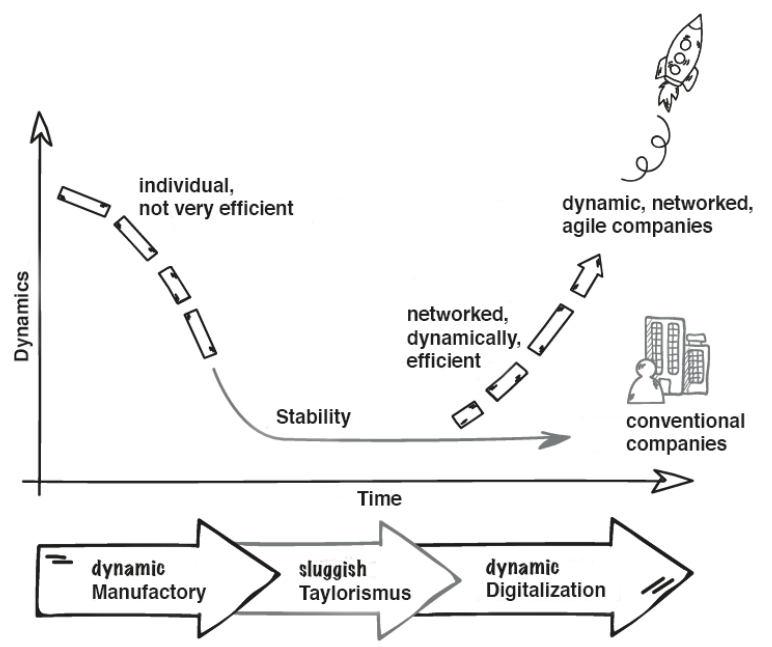

Figure 1. Development of the corporate landscape (Kröger \& Marx, 2020)

Strong product brands often convince not only through quality, because their consumers are conveyed a whole range of emotions and images that are intended to encourage them to buy and long-term loyalty. Marketing consciously relies on messages and communication strategies that trigger a deep emotional bond and identification. In this context, parallels are drawn with the image of organizations as an employer. Just as customers identify with a product brand, so too could employees feel connected to their (socio-economic) organization (Heider-Winter, 2014). Employer branding has adopted this idea, because employer branding interweaves the two business disciplines of branding and personnel management. At the same time, employees can develop their operational competitive advantage even more through identification and motivation (Heider-Winter, 2014; Kröger \& Marx, 2020).

Profound changes in the labor market require an active engagement with employer branding strategies. Megatrends (socio-demographic change, trend towards the knowledge society as well as globalization and networking of the labor market) influence the competition for qualified specialists and managers (Heider-Winter, 2014; Kröger \& Marx, 2020). The demographic development in Germany means that the need for personnel is increasing across all sectors. Qualified specialists and managers must be bound to the organization in the long term. The loyalty of the best minds in the company should - especially in times of crisis help to achieve stability. By 2035, the working society in Germany under the age of 65 will lose 10.8 million people. This contrasts with the shift in the population structure, which is characterized by increased life expectancy and a steep fall in the birth rate (Heider-Winter, 2014; Immerschitt \& Stumpf, 2019). The social economy is thus confronted with immense challenges that are already having an impact. The care sector in particular is under massive 
pressure to recruit skilled and auxiliary workers (Heider-Winter, 2014). Those who do not adapt to these developments in the long term risk the future success of their organization. In any case, the tense skilled labor situation will mean that companies will be able to implement required innovation processes much more slowly. Their flexibility to react to changes in the market is clearly limited (Behr, 2014; Heider-Winter, 2014).

In 2007 the employer evaluation platform kununu was launched in the German market, which was founded in Vienna. In the beginning of the internet age, user-generated content was considered dubious in large parts of the HR community, among other things in the context of employers. 14 years later, 4.9 ratings for 994,000 organizations are posted on kununu. The platforms have now established themselves as important players in the HR market. Organizations are opening up new opportunities to establish innovative business models and create added value for their stakeholders.

The changes caused by the pandemic pose central challenges for the social economy. The results of the survey by the digital association Bitkom show that employer rating portals have a strategic influence on reputation management. The aim of the research contribution is to show social economy organizations in Germany the strategic use of online platforms for employer branding in a profitable way. The focus is on the identification of central value drivers in order to secure the innovative continuity of the organization in the long term. These best practice approaches should help to maintain the organizational ability to act in postcorona times and at the same time to prioritize measures in the context of employer branding.

\subsection{Literature review}

At the end of January 2020, the spread of the infectious disease COVID-19 (corona virus) led the World Health Organization to declare a global health emergency, which had logistical and economic effects on all companies worldwide (Nemțeanu \& Dabija, 2020; Heide et al., 2021). The corona pandemic is accelerating current trends and forcing new solutions to stay competitive (Webb et al., 2020). The health and social sector is subject to permanent change. In this industry too, digital information shapes the "patient-as-consumer" approach (Chaudhri et al., 2021). The competence of the staff forms the basis for the service quality. Due to the changed framework conditions, the human resources (HR) function is increasingly gaining strategic importance (Fahim, 2018). HR activities are increasingly supported by the use of information and communication technologies and are increasingly being discussed in academia. Social media is one of the SMACIT technologies (Social, Mobile, Analytics, Cloud and Internet of Things) and makes an important contribution to digital transformation in the HR context (Martini et al., 2021; Pop et al., 2021). The term "platform economy" has been part of science and practice since the beginning of 2000. Platforms can serve as acquisition channels and strategic sources of information (Kröger \& Marx, 2020; JonkerHoffrén, 2021; Konhäusner et al., 2021). In the age of global connectivity, innovation must be a cornerstone of organizational competitiveness. Digital technologies, platforms and infrastructures have significantly changed the innovation processes in companies as well as the collaborative approach (Chierici et al., 2021). Social media is a powerful platform and can offer added value when looking for competent specialists and executives (Hosain, 2021; Kröger \& Marx, 2020). Social media managers are responsible for the operational management of brands and the presence of organizations in social media and digital platforms (Jacobson, 2020; Kröger \& Marx, 2020). The quality of the customer journey has become a decisive factor in the modern business world. The idea of inspiring customers through service excellence is one of the basics in service research and practice (Jaakkola \& Terho, 2021; Sahhar et al., 2021). In general, the existing marketing literature defines the "customer journey" as a series of touchpoints that customers meet and interact with during their buying process (Boßow-Thies et al., 2020). 


\subsection{Research context}

Social economy organizations provide differentiated, social services for different stakeholder groups. The third sector pursues the goal of closing the gap that cannot be ensured by the state or the economy (Heider-Winter, 2014). The economy is meanwhile also in social economy organizations essential basis for all service processes. The management of scarce goods and the competitiveness of the organization will be given high priority in the future. In the meantime, various projects are settling in the social economy (funded by the European Social Fund) and provide answers to the problems to be solved, such as the shortage of skilled workers, which among others. is shaped by demographic change. Likewise, the increasing conversion of social economy organizations to mercatocratic forms of organization is due not least to a concentration of regulatory and differentiated requirements (Behr, 2014). These structural changes require tailor-made, holistic concepts that need to be managed (Immerschitt \& Stumpf, 2019).

\section{Methods}

The author has analyzed secondary data due to the pandemic in order to identify and systematize HR tendencies. In doing so, available (online) data from Bitkom was used, supplemented by ratings and comments on the web platform for employer ratings kununu.com. The selected exploration methods were primarily used to evaluate the secondary data, as this approach is intended to complete and expand existing problem descriptions. Furthermore, the transformation to the social economy should be dared. For this purpose, an ad hoc sample $(\mathrm{N}=65)$ was used to answer the question "What makes an employer in the social economy attractive?" tries. The people taking part were able to map their attitudes on the 5-level Likert scale and were questioned as part of an external training course for managers from the social economy in Germany. The question was integrated into the educational institution's existing online feedback form. The arithmetic mean, which is part of the method bundle of descriptive statistics, was used for interpretation.

\section{Results}

When comparing the representative studies from the years 2021 and 2018, it becomes clear that around $50 \%$ of the people surveyed - and the trend is rising - inform themselves about employer reviews online. Furthermore, the information obtained is used in the job search. Kröger \& Marx (2020) also state that platforms such as kununu.com or glassdoor.de are used to obtain information. The trend shows that employer rating portals are becoming more and more strategic in recruiting.

The two surveys carried out on behalf of the Bitkom digital association in Germany were used for the analysis. In 2021 1,005 people aged 16 and over were surveyed by telephone, including 854 internet users (Lange, 2021) and in 2018 1,009 people aged 14 and over were surveyed by telephone, including 829 internet users (Gentemann, 2018). Web-based employer rating portals are particularly interesting for working people. $52 \%$ of the people surveyed read the ratings given on the Internet. How an employer is judged also has an impact on the decision for or against a job. $44 \%$ of all respondents who found out about employers state that this influenced their decision to change jobs. $18 \%$ say they were unsettled by the employer reviews, but they decided on the job anyway. $14 \%$ felt encouraged in their decision for the new employer and $12 \%$ decided against the possible change based on employer reviews on the Internet. Another 13\% say the ratings did not influence their decision. $40 \%$ of the respondents had no intention of changing jobs. More than $25 \%$ have already rated their employer on relevant rating portals (Gentemann, 2018; Lange, 2021). 
The following Figure 2 clearly shows that in the social economy, internationalization $($ mean $=3.0)$ and the service portfolio (mean $=2.3$ ) play a subordinate role in attracting employers, compared to the working atmosphere (mean $=4,7$ ), followed by work-life balance $($ mean $=4.5)$, managerial behavior $($ mean $=4.5)$ and job security $($ mean $=4.4)$. The different criteria for employer attractiveness could be evaluated by means of Likert scaling in five levels from does not apply at all $(=1)$ to fully applies $(=5)$.

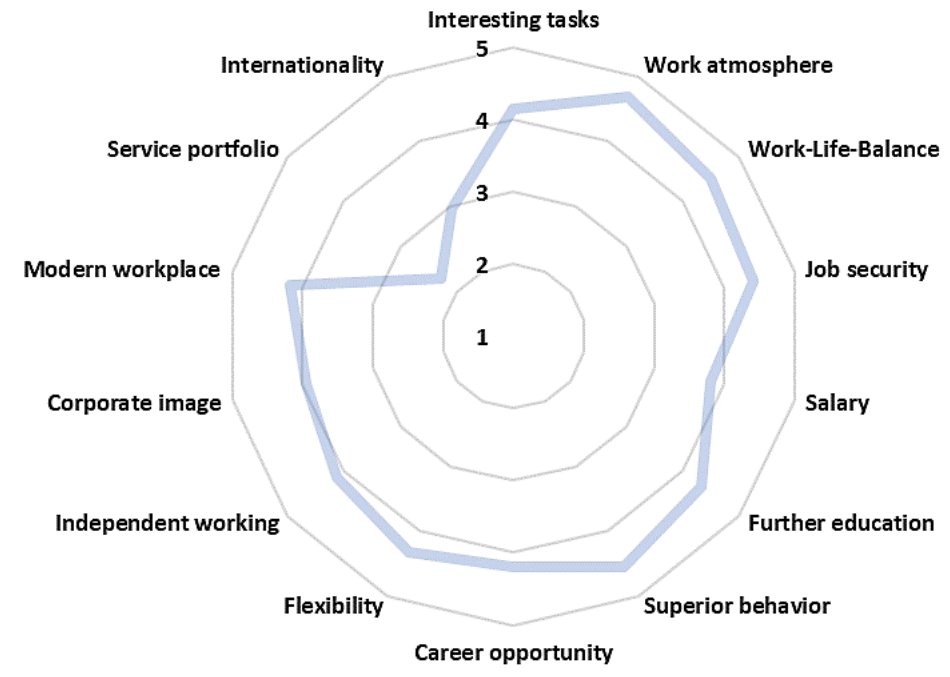

Figure 2. Criteria for employer attractiveness (own illustration)

\section{Discussions}

Employer rating portals are developing into an interactive forum and shaping the image of employers - employer branding, which is supported by social media (Hesse, 2017). The design of an attractive employer brand must be understood as a strategic management task (Kulkarni et al., 2020) in social economy organizations.

The shortage of skilled workers concerns many companies in the DACH region. Certain industries, occupational groups and (geographical) regions have massive problems meeting their skilled labor needs. Previously common methods seem to no longer work these days. There is feverish thought about where and how suitable personnel can be found. Which channels still work for addressing potential specialists and executives? Personnel seekers are therefore desperately looking for new ideas in order to attract the best talent and retain them in the company in the long term (Dannhäuser, 2017; Hesse, 2017). Social media recruiting is now an established miracle cure in the competition against the shortage of skilled workers (Fahim, 2018). In addition to job advertisements on company websites, social media is one of the most popular recruiting channels in German-speaking countries. Due to demographic change, this situation has worsened noticeably in recent years. Various studies from research, business, politics and industry associations confirm this trend. Now more than ever, it is important to secure the best starting position for yourself, to do your own organizational homework and to understand how the handling of the scarce and valuable resource "personnel" is organized at all company levels (Dannhäuser, 2017; Immerschitt \& Stumpf, 2019; Botella-Carrubi et al., 2021).

The communication behavior of stakeholders has changed fundamentally as a result of the Internet. Generation Y (born from 1980) is now integrated into the labor market, making it the first generation that grew up with the Internet and mobile communication as far as 
possible (Bolton et al., 2013; Dabija et al., 2017). In Generation Z (born from 2000) mobile media are integrated into everyday life from childhood. Both generations organize themselves worldwide via social networks and use these networks to exchange ideas on private and professional topics. Experts speak of the loss of organizational information sovereignty. A paradigm shift in communication is emerging and a revolution in the recruiting process is emerging. Depending on the target group and direction, recruiting people use relevant social media channels such as XING, LinkedIn or kununu.com for social recruiting (Dannhäuser, 2017; Hesse, 2017; Kröger \& Marx, 2020).

Megatrends such as digitization, connectivity and changing values are decisive drivers for the radical changes in the world of work (Rock, 2018; Boßow-Thies et al., 2020; Kröger \& Marx, 2020). Traditional status symbols and classic reward systems tend not to inspire the discerning young professionals. Instead, existing systems are critically scrutinized as to how the job can be reconciled with one's own interests and values. For this purpose, personal freedom as well as flexibility in terms of time and infrastructure are demanded by the employer as a matter of course (Dannhäuser, 2017; Kröger \& Marx, 2020). These new realities are forcing companies to rethink and act on a massive scale - also in the social economy.

\section{Conclusions}

The increasing relevance of employer branding strategies for companies has been emphasized in practice and science in recent years, especially against the background of the war for talent (Heider-Winter, 2014; Kröger \& Marx, 2020; Botella-Carrubi et al., 2021). The pressure on companies to evaluate their employer branding strategies has increased significantly in the digital age and will also be of strategic relevance in the future (Fortmann \& Kolocek, 2018). The behavior of applicants has changed radically in many industries - the balance of power has shifted. Applicants are free to choose and companies apply for the best employees.

If you want to take a look into the future, you should evaluate the framework conditions of the organization holistically. In the context of social media recruiting, economy, technology and demographics play a central role. Digitization is constantly changing all industries and requires a modification of previous business models (Boßow-Thies et al., 2020). The employees of an organization are not only a target group, but as ambassadors of a company they themselves become actors in brand management (Heider-Winter, 2014; Kröger \& Marx, 2020). As a brand ambassador in employer branding, you enjoy an outstanding status (Heider-Winter, 2014) and make a strategic contribution to the competitive advantage (Kröger \& Marx, 2020).

In conclusion, the author proposes to empirically check whether eastern EU countries provide comparable results in order to check whether the results can be generalized, especially in the context of the social economy. Furthermore, the questionnaire from the Bitkom study could be expanded and validated with the constructs of employee satisfaction, occupational safety, work-life balance and socio-demographics.

\section{References}

1. Behr, T. (2014). Komplexitätsbewältigung in Betrieben der Sozialwirtschaft. Springer Fachmedien Wiesbaden.

2. Bolton, R. N., Parasuraman, A., Hoefnagels, A., Migchels, N., Kabadayi, S., Gruber, T., Komarova Loureiro, Y. \& Solnet, D. (2013). Understanding Generation Y and their use 
of social media: a review and research agenda. Journal of Service Management, 24(3), 245-267.

3. Boßow-Thies, S., Hofmann-Stölting, C. \& Jochims, H. (2020). Das Öl des 21. Jahrhunderts - Strategischer Einsatz von Daten im Marketing. In Boßow-Thies, S., Hofmann-Stölting, C. \& Jochims, H. (Eds.), Data-driven Marketing (pp. 3-26). Springer Fachmedien Wiesbaden.

4. Botella-Carrubi, D., Gil-Gomez, H., Oltra-Badenes, R. \& Jabaloyes-Vivas, J. M. (2021). Employer branding factors as promoters of the dimensions of employee organizational commitment. Economic Research-Ekonomska Istraživanja, 34(1), 1836-1849.

5. Chaudhri, V., Oomen, T., Pridmore, J. \& Joon, A. (2021). "CARE” in social media: perceptions of reputation in the healthcare sector. Journal of Communication Management, 25(2), 125-141.

6. Chierici, R., Tortora, D., Del Giudice, M. \& Quacquarelli, B. (2021). Strengthening digital collaboration to enhance social innovation capital: an analysis of Italian small innovative enterprises. Journal of Intellectual Capital, 22(3), 610-632.

7. Dabija, D. C., Babut, R., Dinu, V. \& Lugojan, M. (2017). Cross-Generational Analysis of Information Searching based on Social Media in Romania. Transformations in Business and Economics. 16(2). 248-270.

8. Dannhäuser, R. (2017). Trends im Recruiting. In Dannhäuser, R. (Eds.), Praxishandbuch Social Media Recruiting (pp. 1-40). Springer Fachmedien Wiesbaden.

9. Einwiller, S., Ruppel, C. \& Stranzl, J. (2021). Achieving employee support during the COVID-19 pandemic - the role of relational and informational crisis communication in Austrian organizations. Journal of Communication Management, 25(3), 233-255.

10. Fahim, M. G. A. (2018). Strategic human resource management and public employee retention. Review of Economics and Political Science, 3(2), 20-39.

11. Fortmann, H. R. \& Kolocek, B. (2018). Arbeitswelt der Zukunft. Springer Fachmedien Wiesbaden.

12. Gentemann, L. (2018, April 3). Jeder Dritte liest Arbeitgeber-Bewertungen online. Bitkom. https://www.bitkom-research.de/de/pressemitteilung/jeder-dritte-liestarbeitgeber-bewertungen-online

13. Heide, M. P., Heide, M. S., Dabija, D. C. \& Kreis-Engelhardt, B. (2021). Effects of COVID-19 on the glocal management in the orthopedic craft. SHS Web of Conferences, 92, Article 1013.

14. Heider-Winter, C. (2014). Employer Branding in der Sozialwirtschaft. Springer Fachmedien Wiesbaden.

15. Hesse, G. (2017). Auf dem Weg zum Enterprise 2.0: Digitalisierung, Demografie und Wertewandel als Treiber für Change-Management und Kulturwandel. In Dannhäuser, R. (Eds.), Praxishandbuch Social Media Recruiting (pp. 565-590). Springer Fachmedien Wiesbaden.

16. Hosain, M. S. (2021). Integration of social media into HRM practices: a bibliometric overview. PSU Research Review, ahead-of-print.

17. Immerschitt, W. \& Stumpf, M. (2019). Employer Branding für KMU. Springer Fachmedien Wiesbaden.

18. Jaakkola, E. \& Terho, H. (2021). Service journey quality: conceptualization, measurement and customer outcomes. Journal of Service Management, 32(6), 1-27.

19. Jacobson, J. (2020). You are a brand: social media managers' personal branding and "the future audience". Journal of Product \& Brand Management, 29(6), 715-727. 
20. Jonker-Hoffrén, P. (2021). What is the employment potential of a lean platform? The case of Dutch self-employed service professionals. International Journal of Manpower, 42(2), 305-321.

21. Konhäusner, P., Cabrera Frias, M. M. \& Dabija, D. C. (2021). Monetary Incentivization of Crowds by Platforms. Információs Társadalom, 21(2), 97-118.

22. Kröger, J. \& Marx, S. (2020). Agile Marketing. Springer Fachmedien Wiesbaden.

23. Kulkarni, P., Mutkekar, R. \& Ingalagi, S. (2020). Role of strategic management for employee engagement and skill development for start-ups. Vilakshan - XIMB Journal of Management, 17(1/2), 79-95.

24. Lange, F. (2021, April 16). Arbeitgeberbewertungen im Netz beeinflussen Job-Wahl. Bitkom. https://www.bitkom-research.de/de/pressemitteilung/arbeitgeberbewertungenim-netz-beeinflussen-job-wahl

25. Martini, M., Cavenago, D. \& Marafioti, E. (2021). Exploring types, drivers and outcomes of social e-HRM. Employee Relations: The International Journal, 43(3), 788806.

26. Nemțeanu, M. S. \& Dabija, D. C. (2020). Best practices of nongovernmental organisations in combatting COVID-19. In Pamfilie, R., Dinu, V., Tachiciu, L., Plesea, D. \& Vasiliu, C. (Eds.), 6th BASIQ International Conference on New Trends in Sustainable Business and Consumption. Messina (pp. 1-8), ASE.

27. Pop, R. A., Săplăcan, Z., Dabija, D. C. \& Alt, M. A. (2021). The impact of social media influencers on travel decisions: the role of trust in consumer decision journey. Current Issues in Tourism, 1-21.

28. Rock, J. (2018). Algorithm is a dancer: Herausforderungen der Digitalisierung für Wohlfahrtsverbände und Aufgaben der Politik. In Kreidenweis, H. (Eds.), Digitaler Wandel in der Sozialwirtschaft (pp. 27-44). Nomos Baden-Baden.

29. Sahhar, Y., Loohuis, R. \& Henseler, J. (2021). Towards a circumplex typology of customer service experience management practices: a dyadic perspective. Journal of Service Theory and Practice, 31(3), 366-395.

30. Ulrich, P., Scheuermann, I. \& Fibitz, A. (2021). Plattform-Geschäftsmodelle - Status Quo und Potenziale des autonomen Fahrens. In Schulz, W. H., Joisten, N. \&·Edye, C. F. (Eds.), Mobilität nach COVID-19. Grenzen - Möglichkeiten - Chancen (pp. 121-129). Springer Fachmedien Wiesbaden.

31. Webb, A., McQuaid, R. \& Rand, S. (2020). Employment in the informal economy: implications of the COVID-19 pandemic. International Journal of Sociology and Social Policy, 40(9/10), 1005-1019. 